\title{
Validity of the criticism of Ruy Mauro Marini to Latin American development process
}

\section{Keywords: theory of dependence, center periphery, capitalism}

\section{Overview}

After four and a half decades of publication of dialectic of dependency, the thought of Ruy Mauro Marini retains its validity. He is recognized in this author to one of the most genuine representatives approach neomarxist of dependence. His theory of the Superexploitation of the labour force, offers a panorama on the mechanism of action of reliance on Latin America. His thesis elegantly connect the theoretical and methodological principles of Marxism, in the historical and concrete form in which Latin American capitalism has manifested itself. Through a rigorous analysis, Marini shows how Latin American dependence is emphasized as it is belatedly industrialize the region. Among their findings highlight the inability of dependent capitalism for its added value internally, resulting in a transfer of value to the Center. In this mechanism, the technology transfer from the Center to the periphery, become carriers of productive specialization in low value-added goods, which undermines the process of technological change.

\section{Introduction}

The 1950s marked the emergence of the global debate between underdevelopment and development. Decade and a half after the center of the controversy moved towards the newly arisen theory of dependence. Its theoretical origins more important can be placed in the structuralist conceptions, and the influence of Marxist economic theory. In addition, the presence of distortions in the model of industrialization by substitution of imports (ISI), contributed to discuss overcoming underdevelopment through industrialization. The context was ideal for the diffusion of new ideas. According to Sotelo ${ }^{1}$ reflected in unit dialectic, Marini thought continues, as the socio-economic conditions that discovered are maintained in the $21 \mathrm{st}$ century. It conditioned that the International Sociological Association has considered it one of the most important works of the 20th century. The emergence of thought dependentista was conditioned by a double influence: both Keynesian on structuralism, like Marxism on the 2,500-odd, which initiated his theoretical works and that in one way or another were tied to the Economic Commission for Latin America and the Caribbean (ECLAC). In addition, the declining trend of the relationship of unequal exchange between the Centre and the periphery, on the basis of a relationship of power, (in which the first determines the dependence of the second) became the previous doctrinal essence of the nascent theory. An important group of Latin American studies, who established the theoretical stage for further discussions, can be positioned according to Solorza ${ }^{2}$ These include, to summarize the works of Gilberto Freire, José Medina Echavarría, José Carlos Mariátegui and Sergio Bagú among others, which conferred a social interpretation of native. The controversy between Marxist classics and radicals, among them Paul Sweezy and Paul Barán approached the problems of underdevelopment. Its most important authors include André Gunder Frank, which has been recognized by many scholars as the founder of this analytical perspective. The Center environment which revolve their contributions lies in raising the capitalist character

\author{
Volume 2 Issue 5 - 2018
}

\section{Yasmani Jimenez barrier}

Department of Global economy, University of Pinar del Río, cuba

Correspondence: Yasmani Jimenez barrier, Department of Global economy, University of Pinar del Río, Hermanos Saiz Montes de Oca, Cuba,Tel (53) 48779658, Email jimenezbarrera@gmail.com

Received: June 08, 2018 | Published: September II, 2018

of Latin America since its origins, from inserting into the world market in the 16th century. According to Solorza ${ }^{2}$ in addition to this author, Theotonio Dos Santos, Ruy Mauro Marini, Vania Bambirra, Aníbal Quijano, Orlando Caputo are located among others, which adopted an approach neomarxist in their research. The use of the dialectic was a constant in all of them.

\section{Methodology}

The purpose of this article is a review of the literature on theory of dependence on Ruy Mauro Marini. However, authors such as André Gunder Frank, Antonio Serra and Fernando H. Cardoso, with whom the author held controversies that enriched this approach hours are used. Sources of bibliographic own Marini, as well as some of the authors at the discretion of the author are used for this purpose. The article is based on the use of the materialistic dialectic method, which the own Marini showed in his work. It helps as method auxiliary logical historical method, analysis and synthesis, as well as the induccion-deduccion.

\section{Results and discussion}

According to Ruy Mauro Marini, his main theoretical effort lies in the understanding of the study of the laws of the development of dependent capitalism. ${ }^{3}$ It is part of the same alleged that Marx. ${ }^{4-6}$ First issues of the sphere of circulation, are investigated to then investigate the production process. Its interest in highlighting the role of the process of circulation lies in the study of the actual movement of dependent capitalism: "circulation production, linking them to the global market impact drawn on the Organization" internal work, to then return to rethink the problem of circulation". ${ }^{7}$

The effort of Latin America must addressed towards the creation of his native way of circulation, and overcome which was imposed on it, because it provided the dependency. This idea denounces the overcoming of the prevailing order of things. The overcoming of the capitalist relations of production system, leads to the fading of the dependency. Economic relations imposed from the outside, conditioned a dynamic development, unsustainable on the sidelines of the global capitalist system. Distinguish between the situation of dependence and colonial was a nodal issue for Marini. ${ }^{8}$ To critics who claimed previous Marxist approaches, Marini makes it clear that eclecticism 
was a logical consequence of dogmatism against the orthodoxy of some approaches that were considered-yes same-as Marxists. ${ }^{7}$ This explains, to some extent, the shift towards theoretical positions that the claim to enrich Marxism, deny it and inevitably weaken. One of the crucial points in the thinking of the author resides in highlighting that Latin American capitalism, rather than being underdeveloped, is a truncated, capitalism unable to complete its process of development, at the time that the order to prevail capitalist production. The idea held in failure to develop the region in parallel to the development of central capitalism. "Not because they committed abuses against nonindustrial nations that they have become economically weak;" It's because they were weak that abused them". ${ }^{7}$

The Marxist conception clearly evidence the exploitative nature of the capitalist system of production. The interpretation of Marini ${ }^{7}$ insists that the study of the developed capitalism sheds light on its more incipient forms: underdeveloped capitalism. Simple categories research encompasses the essence of more complex categories, equally applies to the social relations of production. The most simple and incipient provide an x-ray of the complex, but these condition the transient or enduring existence of those. The pattern of accumulation of Latin America has been conditioned by the global capitalist dynamics. This phenomenon is displayed as a subordinate between formally independent Nations. ${ }^{7}$ Before this dynamic, the dependence acts as a functional mechanism to the capitalist system, since he temporarily moved the contradictions to the periphery, at the same time, represents a higher level of dependence. On the other hand, Marini stressed the responsibility of the local political elites in the reproduction of the Latin American patterns of dependence. ${ }^{9}$

Here are points of contact with the thesis of André Gunder Frank on the development of underdevelopment. "Today developed countries never had underdevelopment although they may have been little developed". ${ }^{10}$ In this same work cited author defines the relationship between metropoli-satelite, arguing that they cover the whole world."[...] "the cities tend to develop and satellites to subdesarrollarse". ${ }^{10}$ Understood in this perspective, the overcoming of the State dependent on peripheral capitalism didn't find solution to the perpetual system inside. The most suitable output lies in the abolition of the system of capitalist relations of production. The proposal is an order mob, in full correspondence with the Marxist tradition. One of the major limitations of the theory of development lies in assuming that the periphery is a kind of precapitalismo, you need to follow the path to scale development. The author was categorical in this sense: "[...] "more than a precapitalismo, is a sui generis capitalism only charged sense if you look at it from the perspective of the system as a whole, both nationally as, and above all, at international level". ${ }^{11}$

The author shares with Marini the need to underline the role of the Latin American economies in the process of capitalist development, basically as global food supplier, but also as a market of raw materials to industrialization. Why cannot be limited (to Latin American peripheral capitalism) the role of supplier of raw materials, but complementary element to the dynamics of global capitalism, by motivating the displacement in absolute appreciation towards obtaining of relative surplus value. Thus, the place of Latin America in the world economy transcends the simple answer to the requirements of the processes of accumulation in the central countries. Periphery will thus contribute to the axis of accumulation in the industrial economy to move the production of absolute surplus value to the relative surplus value. ${ }^{8}$ The observation made by Marini ${ }^{11}$ regarding the contribution of Latin
America to gain share rise is seen as important. In the deepest legacy Marxist, is assumed, as one of the elements that counteract the fall of the rate of profit the importance foreign trade. This is because the trade relations between the countries produce a reduction in the cost of constant capital, at the same time, this is expressed in an increase of the rate of profit, raising the share of added value and reducing the value of constant capital.

Cycle's economic capitalists are developed on the basis of recurrent fluctuations in the rate of profit, so Latin American peripheral capitalism contributes, in this way, to overcome the contradictions that arise during the accumulation process. As an essential complement, the export specialization of raw materials from Latin America oxygenates the valorization of capital. As same technological change determines the international division of labour (in which the region has among its missions the provide a mass of primary products, according to the needs of the process of capitalist accumulation in the scepter), capitalism Latin American peripheral contributes to the temporal resolution of their most essential contradictions.

The pattern of accumulation that has historically set up in Latin America, responds to the joint that is set between the developed capitalism and the underdeveloped. On the one hand changes in direct reason to changes made in the Centre, while it is expressed, on the other hand, a dependence which manifests itself in of a mediatized development process, structural deformations. The basis of the unit lies in the overexploitation of labour. ${ }^{11}$ However, this particular responsibility of Latin America as a addition to the process of capitalist accumulation (thanks to the lowering of the value of the constant capital by the foreign trade) has meant an economic overexploitation inside of the region, which not seen with the naked eye, it lies in own transfer value that happens towards the Center. Peripheral Nations before the deterioration of the terms of trade, seek to settle the gap increasing the production of primary goods, without paying attention to the differences between the price of the commodity and its value. To reduce your price (with respect to manufacturing goods), a leak of appreciation towards the Center, explaining the deterioration of terms of trade occurs. [...] relations between capitalist economies advanced and dependent, expressing relations of exchange between production systems with different technological levels and, therefore, with different intensities middle of work, normally transfers of value via prices, are operated i.e., make an unequal exchange which corresponds, at the same time, the deterioration of terms of trade to the detriment of the latter. And this is why, also, that they have to resort, as compensation, to increase the magnitude extensive $e$ intensive work to exploit, that is, methods of Super-exploitation of the work related to the production original emphasis. According to Marini ${ }^{11}$ the peculiarity of the Latin American unit lies in the unequal way in which there has been accumulation. While in the Center it has occurred on the basis of the increase in the productivity of labour, on the periphery, instead, has been achieved through the increase of the degree of exploitation of the labour force. From this perspective the region can not realize the surplus value internally, but it is distilled to the Centre in the form of additional revenue because of technological change. Is basically the separation of the process of production of the circulation process, logically consistent with the profile of a deformed and trunco capitalism?

The export of raw materials and importation of goods manufacturing conceal the deficiencies of the Latin American unit. At this point, as an alternative to development is industrialization. 
An industrialization based on low levels of productivity of work, and the overexploitation of the workforce, only modeling a process of accumulation based on absolute surplus value. As can be seen this is atypical, experience shows quite clearly, how central capitalism was developed on basis completely opposed to this reality. The success of the developed capitalism lies in accelerated technological change, which allows obtaining the relative surplus value, which doesn't happen in the frames of a dependent capitalism.

The argument against the process of industrialization in Latin America lays down its limitations. "Latin American industrialization does not create, therefore, as in traditional economies, their own demand, but was created to meet existing demand, and will be structured according to the requirements of market from countries" Advanced "A component of relevance to the work of Marini ${ }^{7}$ was to demonstrate that the ISI strategy, meant the request of Latin American capitalism to a new international division of labour. In essence it's an industrialization of lower stages: upper ones remain in the Centre, who controls the pace of technological change. As Marini ${ }^{3}$ raises the issue of accumulation is a key dependency point, because the development process that constitutes the peripheral capitalism, is subordinated to the logic of operation. In his view, that is the divorce between the production process and the process of circulation, given the conditions sui generis of Latin America. Its essential cause inhabits the superexplotador character of the work, which creates problems of realization. If so, cannot under the prevailing order of things, happen a process of development in the region. The pattern of capitalist accumulation in the periphery cannot operate independently of the developed capitalism.

Dialectic of dependency represents the clearest manifestation of use of dialectical materialism as a method of research in the social sciences. Although some dependency theorists ${ }^{12}$ they tried to downplay this work, its content reflects an understanding of Marxism in all its dimensions. So Marini ${ }^{11}$ presents a defence, on the one hand showing the importance of Marxism in the proper interpretation of the process of development in Latin America, and on the other hand, indicates the inadequacy of theoretical and methodological rigor of these authors. One of the limitations of these authors that criticize the work of Marini ${ }^{7}$ lies in the confusion of key categories. The question of confusion is always dangerous, in the social sciences; the confusion is more dangerous than imprecision. Some key categories of the Marxist system are value and price, which not is properly understood by Serra. ${ }^{12}$ According to Marx (1973rd) price, is a form of value, while the value expresses an essential relationship, and price, a formal type, which is a clear manifestation of fetishism that causes the action of the law of value. Marini ${ }^{3,7,11}$ exposes this point as a critical element. Not understanding this dialectical relation of the categorical system of Marxism, necessarily leads to the crude popularization of Capital.

Dialectic of dependency is located on a higher plane of analysis, whereas previous economic thought (the theoretical effort from some previous Marxists, both the same-CEPAL) in Latin America. The theory of the unit inside, some proven analytical deviations can be examined. You can be or not in accordance with the criteria exposed in this work, but their scientific criticism beyond simplistic theoretical and methodological-fairly common in modern economic science. The originality of this work expresses understanding of the Marxist method in its entirety, and constitutes an important contribution to apply it to a concrete reality, that might not be the task of the Capital for the reasons already stated.

\section{Conclusions}

The document outlined the importance of the use of the method of research of Marx in the understanding of the global capitalist dynamics, in particular for Latin America. The validity of Ruy Mauro Marini represents continuity with the Marxist analysis, as theorizing for Latin America was not its object of research in the Capital. Dialectics of the dependence of Ruy Mauro Marini, more than four and a half decades of published, offers a panorama of fairly consistent with Marxist logic adapted to the Latin American context. The attempt to analyze the peripheral capitalism in the Marxist tradition is a merit, have done in such a way elegant and original, expresses the generality of dialectical materialism to capitalist relations systemic understanding of production. It showed the consequences of an economic inclusion based on comparative advantages imaginable on the basis of the Super-exploitation of the workforce, against the developed capitalism. The current thinking of Marini acquires monumental dimensions. The maintenance of the international economic order which Marini criticized prevails, and tends to hegemonize the thinking of future generations in the context of globalisation. The reading of dialectic of dependency is a timeless treat native, critical thinking and towards the systemic dimension of the critique of political economy. Its validity remains as exist the capitalist mode of production and its manifestation: the dependent capitalism.

\section{Acknowledgements}

None.

\section{Conflict of interest}

The author declares that there is no conflict of interest.

\section{References}

1. Sotelo Adrian. Entry into force of the thought of Ruy Mauro Marini and theory dependence. Texts \& contexts. 2017;16(1):29-48.

2. Solorza Marcia, Cetre Moses. The theory of dependence. Republican magazine. 2011;(10):127-139.

3. Marini Ruy M. A round dialectic of dependency (postscriptum), in Martins, Carlos Eduardo Latin America, dependence and globalization. Conceptual foundations Ruy Mauro Marini. Bogota: century of manCLACSO; 1973b. 5 p.

4. Marx Carlos. Capital, volume I. La Habana: Editorial de Ciencias Sociales; 1973a. 549 p.

5. Marx Carlos. Capital, volume II. La Habana: Editorial de Ciencias Sociales; 1973b. 319 p.

6. Marx Carlos. The Capital, Volume III. La Habana: Editorial de Ciencias Sociales; 1973 c. 645 p.

7. Marini Ruy M. dialectic of dependency, Martins, Carlos Eduardo Latin America, dependence and globalization. Conceptual foundations Ruy Mauro Marini. Bogota: century of man-CLACSO; 1973. 19 p.

8. Sader Emir. In dialogue with dialectic of dependency of Ruy Mauro Marini. New society. 2012;22(238):55-59.

9. Osorio Jaime. On dialectic, overexploitation and dependence. Notes on dialectic of dependency. Arguments. 2013;26(72):57-73.

10. Frank Andre G. The development of underdevelopment. Critical thinking. 1967;18(4):159-172. 
11. Marini Ruy M. The reasons for the neodesarrollismo in Martins, Carlos Eduardo Latin America, dependence and globalization. Conceptual foundations Ruy Mauro Marini. Bogota: century of man-CLACSO; 1978. $220 \mathrm{p}$.
12. Serra Joseph, Cardoso Fernando H. The misadventures of the dialectic of dependency. Revista Mexicana de Sociología; 1978. 290 p. 